Scientific and Industrial Research, will be published elsewhere.

G. G. E. SCUDDER

Hope Department of Entomology, University Museum,

Oxford. March 29.

${ }^{1}$ Snodgrass, R. E., Smithson. Misc. Coll., 89, Pt. 1 (1933).

"Snodgrass, R. E., "Principles of Insect Miorphology" (New York and London, 1935).

"Asahina, S., "A Morphological Study of a Relic Dragonfly Epiophlebia. superstes Selys (Odonata, Anisozygoptera)" (Tokyo, 1954).

4 Walker, E. M., Ann. Ent. Soc. Amer., 36, 681 (1943).

${ }^{5}$ Michener, C. D., Ann. Ent. Soc. Amer., 37, 336 (1944).

\section{Development of Beet Eelworm, Heterodera schachtii Schmidt, in the Wild Beet, Beta patellaris}

OBSERvations made by Hijner ${ }^{1}$ suggest that, while the roots of the resistant species of wild beet, Beta patellaris, are invaded by larvæ of the beet eelworm, Heterodera schachtii, no further development occurs beyond an early larval stage.

It has now been found that not only do a large proportion of the larvæ which enter the roots of $B$. patellaris develop to the intermediate or third larval stage, but also that a small percentage develop to maturity, becoming males. This was shown by growing plants singly in $2 \frac{1}{2}$-in. pots and adding 2,000 larvæ, hatched from cysts in sugar beet root diffusate, to each pot. The plants were then left for periods of from one to six weeks after the addition of larvæ, there being four plants in each group, making twenty four plants in all. The roots of each plant were examined for larval stages of the parasite by the usual process of staining in boiling acid-fuchsin, weighing the stained root system and macerating in a domestic blender. The contents of the blender were then washed thoroughly through a 60-mesh sieve and aliquots placed in ringed Petri dishes, when the larvæ were counted under a binocular microscope.

It was found that about 15 per cent of the larvæ added invaded the roots and that, of these, about 65 per cent developed to the intermediate stage and about 7 per cent reached maturity. Even at the end of the six-week period no mature females were found, nor any immature individuals which could with certainty be identified as female. The remaining 35 per cent of the invading second-stage larvæ were either present in a deteriorated condition in the roots or had disappeared. This was also so with the majority of the intermediates.

This state of affairs appears to be a very close parallel to the pattern of development shown by Jones $^{2}$ to occur with the potato root eelworm, Heterodera rostochiensis Woll., in the wild potato, Solanum tuberosum sub sp. andigena, where, however, a few females have been found to develop also. It is possible that in further investigations this may also be found to be true of Beta patellaris.

I should like to thank Mr. F. G. W. Jones for his advice and also Miss M. Wolfe for technical assistance. I am indebted to the Sugar Beet Research and Education Committee for providing the facilities for carrying out this work.

School of Agriculture,

\section{AUDREY M. SHEPHERD}

University of Cambridge. May 30.

${ }^{1}$ Hijner, J. A., Med. Inst. v. Rxi. Suikerproductie, 21, 1 (1951).

¿ Jones, F. G. W., Ann. Appl. Biol., 41. 348 (1954).

\section{Diego Blood Group in Negro}

Among the various blood groups employed in anthropology, the Diego is one of the most peculiar to the study of human races.

In Negroes, hitherto the only reference has been the initial paper by Layrisse, Arends and $\mathrm{Sisco}^{1}$, who found among 150 mixed Negroes that $7 \cdot 3$ per cent had the Diego antigen; but they emphasized the Indian mixture in their stock. We have had the opportunity of testing 120 pure Negro donors of the Instituto de Hematologia da P.D.F., with negative results. The anti-globulin method was employed, with anti-Diego serum, available from Dr. Layrisse.

We believe these results show that the Diego blood group is of capital importance in anthropological research, for the aid it gives in studying the origin, composition and mixture of populations.

We thank Dr. Miguel Layrisse for the supply of the anti-Diego serum.

\section{P. C. JUNQUEIRA}

P. J. WISHART

Serviço Immuno-hematologia,

Instituto de Hematologia da P.D.F., Rio de Janeiro. May 28.

${ }^{1}$ Layrisse, M., Arends, T., and Siseo, R. D., Acta Med. Venez., 3, 132 $(1955)$.

\section{Mechanism of Contraction of Smooth Muscle by Drugs}

IT is generally believed that the process which initiates contraction in striated muscle is the depolarization of the excitable membrane of the muscle fibre, although the mechanism by which membrane excitation is linked with the contractile process is unknown ${ }^{1}$. When smooth muscle is caused to contract by acetylcholine there is a decrease in membrane potential ${ }^{2}$, and it would seem reasonable to assume that the sequence of events following action of the drug on the excitable membrane is similar to that postulated for striated muscle, namely, depolarization leading to activation of the contractile element. The following experiments in which the effects of drugs were tested on smooth muscle which had been depolarized by the external administration of potassium ions suggest, however, that activation of the contractile element can be initiated by acetyl. choline and other drugs without intervening depolarization.

Isolated preparations of smooth muscle, including the nerve-free amnion of the chick, rat uterus, and separated longitudinal muscle coat of the cat's small intestine, were immersed in Ringer's solution, and their contractions in response to drugs and electrical and mechanical stimulation recorded isotonically. When the sodium chloride of the Ringer's solution is replaced by 'isotonic' potassium chloride $(12 \cdot 3$ $\mathrm{gm}$./l.) or potassium sulphate $(22 \mathrm{gm}$./1.) the preparation at first shortens maximally, but soon begins to relax. The degree of relaxation varies in different preparations, but its speed and extent can be increased by lowering the temperature or addition of adrenaline or isoprenaline. These preparations continue to respond to acetylcholine, histamine, 5hydroxytryptamine and oxytocin when suspended in potassium Ringer. The effect of acetylcholine in potassium Ringer is antagonized by atropine. The 